Systematikken i afhandlingen er uklar og ujævn. Det er hverken læsevenligt eller hensigtsmæssigt at anbringe problemformuleringen på side 75 , metodiske reflektioner på side 91 og redegørelser for begrebsuklarheder inden for emnet på side 96 uden forinden at have klargjort for læserne, hvilke begrebsdefinitioner forfatteren selv benytter sig af.

Men emnet er vigtigt og bogen derfor anbefalelsesværdig, fordi den bringer opmærksomhed til et emne, som bliver stadig mere påtrængende: i hvilket omfang retten fortsat skal fungere som konfliktløsningsforum par excellence, eller retten snarere bør ses som et tilbud på lige fod med andre, hvis styrke skal måles alene i kraft af deres evne til at bringe en reel, ikke blot formel afslutning på konflikten.

Vibeke Vindelov

Københavns Universitet

\title{
Summaries in English
}

Criminal Law Theory and the Legislator. [Straffrättsteorin och lagstiftaren]. By Kimmo Nuotio, Helsinki University. Pp. 1-3.

The article deals with questions having to do with the relation between theoretical legal research and the practical reform work performed by the lawmaker in the field of criminal law. When the legislative reform work touches upon questions bearing a close relation to theoretical matters, especially the general requisites of penal liability, the lawmaker has to take a stand on theoretical questions. Theoretical and principled knowledge of criminal law then becomes crucial also from the point of view of law reform work. Rational reform work requires that the state of law before the reform is known. In this article a certain tension is being analysed based on the Finnish experiences: The effort of drafting detailed and exact provisions on theoretical matters is not supported enough by evaluative analysis provided by theoretical studies concerning grounds of penal liability. The close participation by criminal law professors in the law drafting does not by itself automatically guarantee that the right kind of knowledge is available for law reforms. Legal research should clearly seek to influence the development of law in more intermediate ways. Some problems having to do with efforts to draft provisions on general legal principles are pointed out.

Empiricism and Ideology in Criminology. [Empiri og ideologi i kriminologi: Den objektive og subjektive siden av kriminaliteten i Island]. By Helgi Gunnlaugsson, Islands Universitet, Reykjavik. Pp. 14-26.

This research examines the relationship between results obtained from different methodologies. Using crime survey data, press reports on crime and crimes known to the police a broad picture of the crime situation in Iceland emerges. It appears that the Islandic public is more concerned about crime than earlier and that crime reporting is more frequent in the media despite the fact that police data does not show significant changes in recent years. Given this observation, the concept "Moral Panics" is evaluated, raising the question whether a crime crisis has developed in Iceland, as reflected in inflamed public 
opinion and press reports. While there seems to be little factural basis for such a panic, it is argued, among other things, that the crime situation in Iceland has changed significantly during the past few decades which might help explain a deeper crime concern.

Local police and local culture. [Bydelspoliti og lokalkultur]. By Oddrun Saeter, The Norwegian Building Research Institute, Oslo. Pp. 27-44.

This is a study of police work in a suburban area of small houses in a large Norwegian town. The article focuses on the issue of control, and the relation between the primary control, or more broadly the "local culture", and the police control. Does the context of the local police represent a new kind of Panopticon? Or can the local people and the police find common ways of controlling the criminality in the area?

The police have a lot of contacts with the local people in their daily work. The police function as mediators and conflict dealers, they teach young people about law and criminality, they visit young people arranging "being at home alone-parties", they patrol the streets. People also visit the police office to get help with their civil inquiries or they ask for help in more severe cases. Or they just come there for talking and drinking coffee with the police...

The criminality has been reduced in the area after the police came there. The study points to the common values of the people and the police. This is considered (by the researcher) as the main reason for why the police can intervene as they do. Even the youth welcome the police control, and appreciate the visibility of the police. The further questions are like these: Can the local agreement be too extensive, and turned towards all kinds of deviant behaviour? And: Can the police experiences from this area be used in a multicultural area, and how? Some answers will be worked out in a new study in 1995-96.

Serial Rapists. [Serievåldtäktsmän]. By Henrik Belfrage. Pp. 45-57.

This article describes a Swedish interdisciplinary research project on serial rapists. The main result is that the recidivism rate into new sexual crimes is very high, regardless of type of sanction. However, the recidivism was considerably lower among those who recieved long term group therapy treatment. The result is promising, but the study group is small, and more research work is needed before any certain conclusion can be drawn.

The Effect of Reoffending on the Choice of Sanction and Sentencing. [Återfallets inverkan vid påföljdsval och straffmätning]. By Pia Rudolfsson. Pp. 58-71.

The main subject is the fact that Swedish courts, when choosing a penal sanction and meting out the sentence, may take into account the circumstance that a particular crime involves reoffending. The article describes the development in this field in Sweden and highlights the Swedish legislators' changes of opinion over the years concerning what impact recidivism should be given in criminal cases. 